\title{
The case of determining the species, gender, age and race of the skull with congenital multiple developmental anomalies
}

\author{
Anastasiya Stoyan', Saule Mussabekova² \\ ${ }^{1}$ Medical and Forensic Department, Institute of Forensic Expertise, Forensic Examinations Center of the Ministry of Justice of the Republic of Kazakhstan, Almaty, \\ Kazakhstan \\ ${ }^{2}$ Department of Pathology, Karaganda Medical University, Karaganda, Kazakhstan
}

Received: 2021-10-13.

Accepted: 2022-01-28

This work is licensed under Creative Commons Attribution 4.0 International License

\section{J Clin Med Kaz 2022; 19(1):80-84}

\section{Corresponding author:}

Saule Mussabekova.

E-mail: musabekovaS@qmu.kz;

ORCID: 0000-0001-9622-8218

\begin{abstract}
In forensic medicine, a reconstructive victim profile is a widely used procedure for providing individual data in cases of complex identification of a person. The most valuable data such as gender, age, origin and height are obtained from skeletal and dental analyses. Deformed skulls require special expert attention during the forensic examination of bone remains. Unusual skull shapes are usually formed with certain diseases (hydrocephalus, craniostenosis, rickets), various kinds of injuries or as a result of artificial (intentional) changes in the shape of the head. The detection of cranial deformity has a great forensic importance in identifying a person, allowing you to further outline the range of diseases that an unknown person could have suffered during his lifetime. The article describes a rare forensic case of identification of a human skull with congenital multiple developmental anomalies. During the forensic medical and forensic examination, the deceased had a history of signs of a rare disease characterized by the formation of a specific deformation of the skull. A comprehensive assessment of the data is very important when conducting forensic medical studies aimed at helping investigative authorities to identify human remains.
\end{abstract}

Key words: forensic medical examination, skull, deformity, developmental anomalies, identification

\section{Introduction}

In the research, forensic identification of a person of bone remains can present significant difficulties for forensic experts [1,2]. Difficulties in identifying bones arise during the destruction of bone tissue as a result of exposure to high temperatures, chemical and other factors, as well as when several corpses are found in one burial $[3,4]$. The skull and long tubular bones remain the most informative for determining gender, age and individual anthropometric data [5,6]. For the present, a number of problems remain in identifying a person's identity, despite the improvement of biometric identification and DNA analysis methods $[4,7]$. This is primarily due to the processes of race mixing, a characteristic trend of modern humanity, which leads to a change in the main craniometric parameters of the skull $[1,5,8]$. On the territory of the Republic of Kazakhstan, the mestization of the population is directly related to migration processes. In this region, the formation of a contact zone (the zone of fusion of Caucasians and Mongoloids) [2] is clearly traced, which is caused by many factors, including the deportation of the people of the former USSR during the repressions, the evacuation of the population during the Second World War and the subsequent processes of globalization. As a result, the number of Mestizos living in this territory is steadily increasing, creating certain difficulties in the racial identification of bone remains. The digital indicators existing in the methods for identifying a person by bone remains are somewhat outdated, in addition, in most cases they are adapted exclusively for the identification of the Caucasian population of central Russia. The use of these data for the multinational ethnic composition of the Republic of Kazakhstan is poorly justified, since they can be interpreted incorrectly due to the processes 
of acceleration and urbanization of the local population. At the same time, individual innate and acquired bone features has a particular importance $[9,10]$. However, the differential diagnosis of gender, age and race in congenital anomalies of the development of the skull bones in forensic medical practice is difficult, because anomalies of the development of the skull lead to changes in metric, anatomical, morphological and radiological signs $[5,11,12]$. At the same time, situations when it is necessary to identify the identity of skeletonized human remains continue to be very popular. In this regard, an interesting example of a medical and forensic examination of bone remains found in the Almaty region.

\section{Case presentation}

Not far from the farm "Zhylkibayev", located near the village of Shengeldy, Almaty region, skeletal fragments were found, presumably belonging to a missing person who became a victim of murder. For identification of the person, the material was transferred for medical and forensic examination to the Institute of Forensic Examinations in Almaty, RSME "Center for Forensic Examination of the Ministry of Justice of the Republic of Kazakhstan". The skull, four cervical, three thoracic and two lumbar vertebrae, five ribs, left femur, left and right tibia were presented for the research. The bones presented for examination are white with a yellowish tinge, dry, light, completely devoid of soft tissues. A comparative analysis of the morphology of the skull bones revealed a pronounced deformation in the occipital bone, forming a hemispherical protrusion (Figure 1, Figure 2).

Figure 1 - Skull, front view (no visible changes)

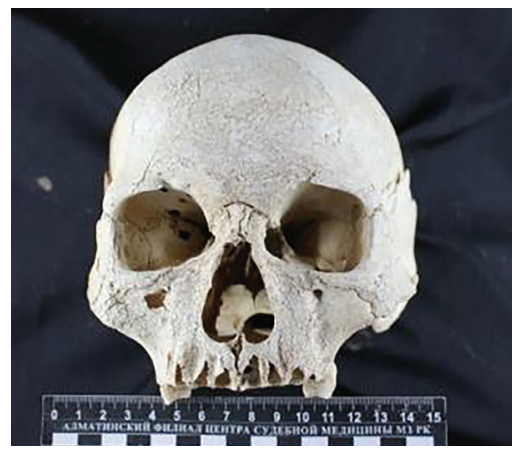

Figure 2 - Skull, left view (the arrow indicates the deformity in the occipital bone)

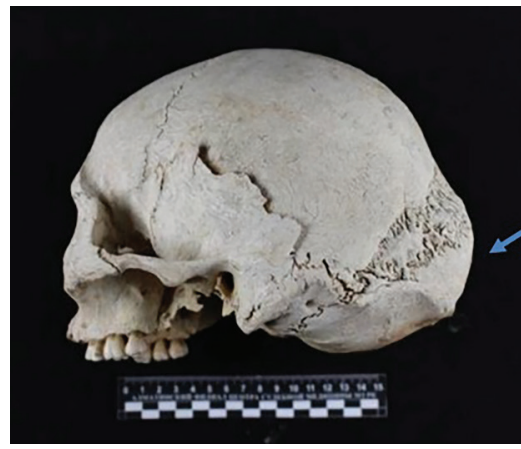

The interparietal suture is deformed and deviates to the left in its apical and bregmatic parts (Figure 3). The occipital suture is represented by significantly overgrown teeth, has a width of up to $35 \mathrm{~mm}$ (Figure 4).
Figure 3 - Skull, top view (the arrow indicates the described changes)

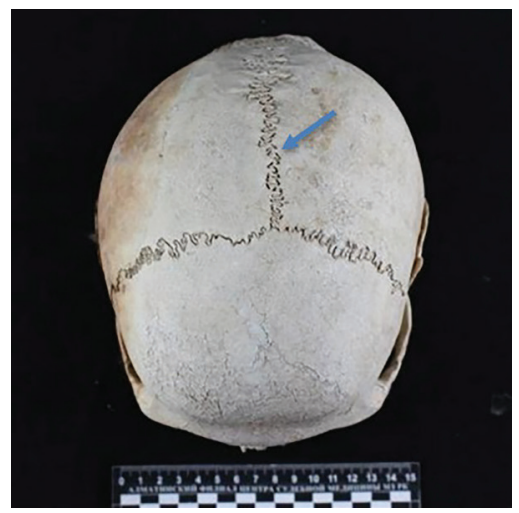

Figure 4 - Skull, back view (the arrow indicates the described changes)

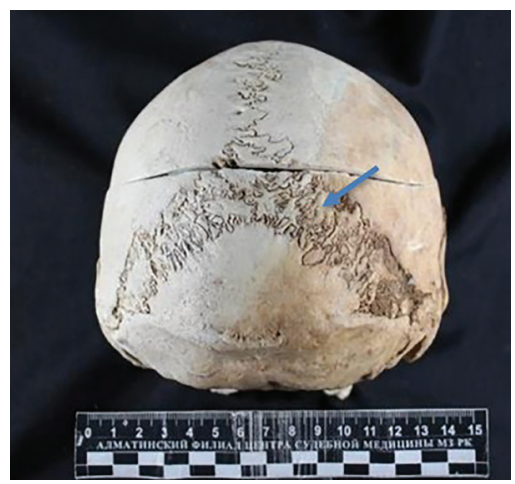

For further investigation, the cranial cavity was opened with the help of an angular saw passing through the frontal and parietal bones. When measuring the base of the skull using anthropological craniometric instruments and subsequent comparison of anatomical characteristics, it was revealed: a decrease in the size of the anterior and middle cranial pits, an increase in the size of the posterior cranial fossa, a decrease in the length of the Blumenbach slope and a flattening of the base of the skull (Figure 5). The mastoid processes are reduced, the awl-shaped processes are reduced, one horizontal abnormal suture of the occipital bone departs from the occipital-mastoid sutures (Figure 6). The circumference of the skull is $555 \mathrm{~mm}$, the longitudinal diameter is $195 \mathrm{~mm}$, the transverse is $148 \mathrm{~mm}$. The thickness of the frontal and parietal bones corresponds to the norm, the occipital bone is somewhat thinned.

When establishing the race of the investigated skull, out of 28 craniometric indicators of the external structure of the skull [1], 21 indicators were identified, confirming the Mongoloid origin. 3 indicators were identified as probable Caucasoid signs. The remaining 4 craniometric indicators of the examined human skull could not be identified due to the absence of a part of the dental apparatus. Additionally, a comparative analysis of the cranioscopic parameters of the examined skull was carried out with similar indicators of 10 skulls of men of the Mongoloid race taken from the regional database (there are no female skulls of the Mongoloid race in the regional database). It should be particularly noted that from 25 generally accepted cranioscopic indicators, 3 indicators (forehead width, condylar and bigonal width) were not studied. This is due to the fact that on some skulls the frontal bone and lower jaw were missing. 
Figure 5 - View of the base of the skull from the inside (the arrow indicates the described changes)

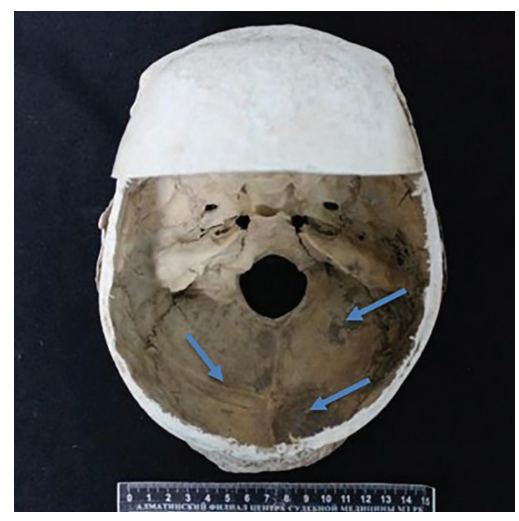

Figure 7 - X-ray picture of the skull in Hajdu-Cheney syndrome (there is an underdevelopment of the bones of the facial skull, protruding frontal and occipital tubercles, wide cranial sutures)

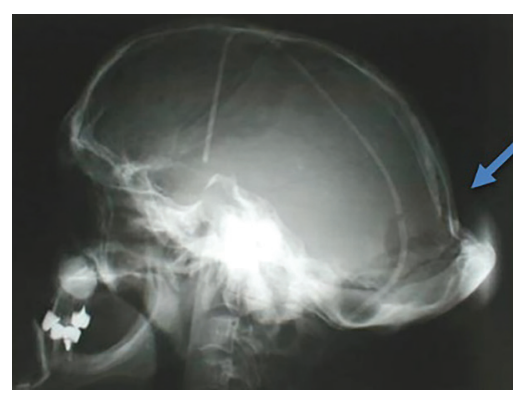

For the convenience of comparison, for each of the studied 22 signs, the smallest, average, the largest indicators were used, which are respectively designated as uncertain (U), probably male (PM), reliably male (RM) and probably female (PF). The results of the comparative research are presented in Table 1.
Figure 6- View of the base of the skull from below (the arrow indicates the abnormal seams of the occipital bone)

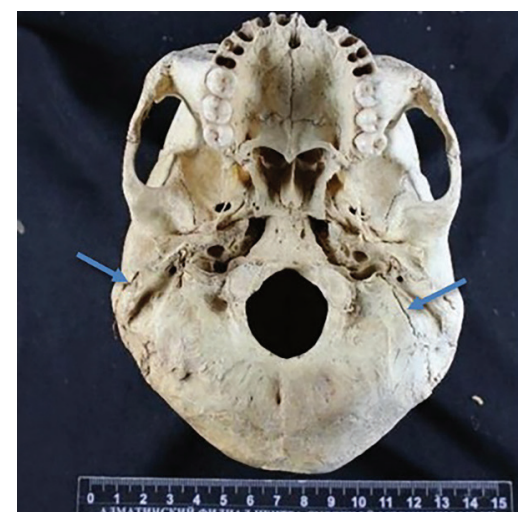

Figure 8 - Appearance of a patient with Hajdu-Cheney syndrome (hypertelorism, bushy eyebrows, micrognathia, low set ears and short neck present)

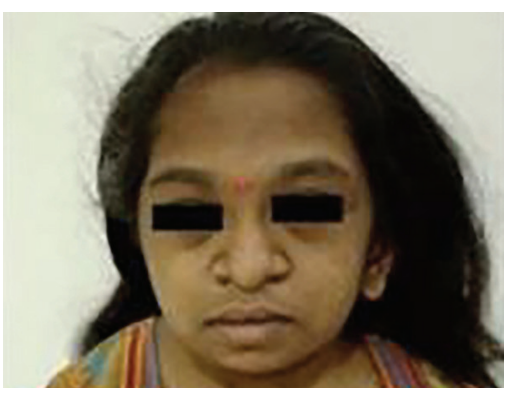

It was found that from 22 signs, 14 exceed the average indicators, while 7 of them exceed the largest values. The analysis of the results showed that the skull provided for the research has metric characteristics that differ from most indicators characteristic of the skulls of the Mongoloid race.

Table 1

Cranioscopic signs of the examined skull

\begin{tabular}{|c|c|c|c|c|c|c|}
\hline \multirow[t]{2}{*}{ No } & \multirow[t]{2}{*}{ Indicator } & \multirow{2}{*}{\begin{tabular}{|l|}
$\begin{array}{l}\text { Measures of } \\
\text { examined skull }\end{array}$ \\
\end{tabular}} & \multicolumn{3}{|l|}{ Indicator } & \multirow[t]{2}{*}{ Indication } \\
\hline & & & the smallest & average & the largest & \\
\hline 1. & Longitudinal diameter & 195,0 & 145,0 & 142,8 & 187,0 & RM \\
\hline 2. & Transverse diameter & 148,0 & 115,0 & 139,1 & 148,0 & PM \\
\hline 3. & High altitude diameter & 130,0 & 87,0 & 123,0 & 138,0 & $\mathrm{U}$ \\
\hline 4. & Length of the base of the skull & 101,0 & 95,0 & 109,8 & 155,0 & PM \\
\hline 5. & Width of the base of the skull & 137,0 & 116,0 & 128,5 & 136,0 & RM \\
\hline 6. & Nape width & 139,0 & 113,8 & 116,1 & 121,0 & RM \\
\hline 7. & Mastoid width & 115,0 & 101,0 & 108,8 & 119,4 & PM \\
\hline 8. & Skull circumference & 555,0 & 520,0 & 534.3 & 560,0 & RM \\
\hline 9. & Sagittal chord & 140,0 & 135,0 & 144,7 & 175,0 & PM \\
\hline 10. & Frontal chord & 112,0 & 111,0 & 117,5 & 119,0 & PM \\
\hline 11. & Parietal chord & 111,0 & 112,3 & 114,6 & 117,0 & PM \\
\hline 12. & Length of the large occipital foramen & 37,0 & 33,0 & 35,2 & 37,0 & PM \\
\hline 13. & Width of the large occipital foramen & 33,0 & 26,0 & 29,5 & 32,0 & PM \\
\hline 14. & Bizygomatic diameter & 141,0 & 140,0 & 142,0 & 144,0 & RM \\
\hline 15. & Face base length & 102,0 & 63,0 & 91,6 & 106,0 & PM \\
\hline 16. & Upper face height & 67,0 & 63,0 & 69,0 & 74,0 & $\mathrm{U}$ \\
\hline 17. & Full face height & 114,0 & 114,0 & 115,0 & 116,0 & $\mathrm{U}$ \\
\hline 18. & Upper face width & 109,0 & 98,0 & 86,3 & 125,0 & PM \\
\hline 19. & Average face width & 103,0 & 91,0 & 100,0 & 106,0 & PM \\
\hline 20. & Nose height & 56,0 & 42,0 & 52,2 & 57,0 & RM \\
\hline 21. & Width of the orbit (left) & 41,8 & 38,0 & 40,0 & 42,0 & $\mathrm{PF}$ \\
\hline 22. & The height of the lower jaw body & 34,0 & 32,0 & 33,0 & 34,0 & PM \\
\hline
\end{tabular}

Notes:

PF - probably female

PM - probably male

RM - reliable male

$\mathrm{U}$ - uncertain 
When examining the skull to establish somatic gender, only 23 parameters out of 25 parameters accepted in forensic medical practice were identified. It was not possible to determine 2 parameters, due to the complete absence of the left branch of the lower jaw. There were 6 reliably male signs, probably male -12 , uncertain -4 and probably female -1 .

When determining the age, it was found that: the teeth on the examined skull of the coronal suture were smoothed in the temporal and bregmatic parts, which corresponds to the age of about 30-40 years. At the same time, the interparietal suture is partially smoothed in the back, which corresponds to 20-30 years. The degree of occipital suture overgrowth was not evaluated due to the presence of anomalies in the development of the skull. The wedge-frontal, wedge-parietal and wedge-temporal sutures are smoothed, but not overgrown throughout, which corresponds to an age of less than 40 years. On the inside of the skull sutures, the coronal suture is overgrown, the rest of the sutures are smoothed, which corresponds to an age of less than 40 years. A comprehensive analysis of the data obtained showed that the degree of overgrowth of the skull sutures corresponds to the age of 20 to 40 years, however, taking into account the presence of anomalies in the development of the skull, the result of the study may have relative significance.

\section{Discussion}

The results obtained convincingly indicate that the anatomical and physiological features of the bones of the skull under study are characteristic of basilar impression, in which the base of the skull is flattened, the dimensions of the anterior and middle cranial pits at the level of the Turkish saddle are reduced, and the length of the Blumenbach slope is also reduced [13,14]. According to some authors, basilar impression is rarely isolated and often occurs in such genetic diseases as Hajdu-Cheney syndrome, Gorham syndrome and others [12,14,15]. HajduCheney syndrome is a rare autosomal dominant congenital connective tissue disorder characterized by severe and excessive bone resorption, leading to osteoporosis and a wide range of other possible symptoms [12]. Patients may have a peculiar phenotype, which characterized by a small lower jaw, a thick depression in the back of the head, osteoporosis, low height, dislocations of bones, a short neck, thick eyebrows, thick hair, high or low palate and low-lying ears (Figure 7, Figure 8) [16].

Gorham-Staut disease is an extremely rare disease characterized by osteolysis due to anomalous proliferation of blood vessels. In the case of the onset of the disease in childhood, skeletal deformities develop. Bone loss can occur both in one bone and in several, involving soft tissues in this process [13]. The course of the disease is variable and unpredictable. Involvement of the bones of the skull and spine in the process is unfavorable in prognostic terms. However, there are cases when people with this nosological form lived up to 70 years [11,13]. In our case, the bones of the arch and the base of the skull also had pronounced finger-like indentations (Figure 5), which indicates the presence of pronounced intracranial hypertension in the during his lifetime.

The racial affinity of the examined skull was carried out solely for the purpose of identifying human remains. However, one of the main problems of human identification is that the emergence of racial hybridity is not taken into account [7]. According to a number of authors, skeletons currently show features "typical" of two or more racial groups and it is very problematic to attribute them to one specific racial group $[3,17]$. World migration has further strengthened categorical ideas about biological variations, and some authors emphasize the important influence of socio-geographical environmental factors on the shape of the human skeleton [18]. At the same time, some authors emphasize that when conducting a forensic medical examination, one should be fully aware of the presence of many biological inaccuracies when identifying human remains $[3,7]$. However, there is also a point of view according to which it is necessary to form databases characterizing specific craniometric indicators of populations for each region separately, since the geographical movement of people occurs on a very large scale and leads to an increase in populations of mixed individuals $[1,7,19,20]$.

The solution of the issue of the gender of bones has the greatest practical importance in forensic medical examination, because, in the identification process, it allows to reduce the number of wanted persons by half. However, in human populations, the degree of difference in size characteristics between men and women may be small $[17,19]$. The size range within each gender is widely superimposed so that only the smallest women and very large men are outside the overlap range of indicators of the opposite gender, in addition, it is necessary to take into account the racial and ethnic characteristics of the population $[2,10,20]$. Diagnosis of gender by the skull can be complicated by various factors, including environmental, occupational, as well as nutritional characteristics and pathological changes due to diseases $[4,21,22]$. The craniometric approach allows to unify the degree of human identification, however, the craniometric method of determining the gender of V.I. Pashkova used in the CIS countries requires certain additions and changes, since it was originally based on the research of skulls belonging exclusively to people of Russian nationality aged 22 years and older who lived in the north-west of Russia. In addition, this technique is not recommended for use in the study of deformed, fragmented skulls and remains exposed to high temperature, as well as the skulls of children [10]. According to many researchers, the significance of various signs is not the same, and therefore, the use of a combined application of craniometric and cranioscopic approaches is recommended $[2,7,19]$.

The solution of the tasks is impossible without an integrated approach to the research of the totality of all diagnostic and identification features of the human skeleton. Based on the conducted research, it was found that the skull most likely belonged to a man of the Mongoloid race with the presence of separate Caucasoid features. The age of the unknown ranged from 20 to 40 years, but at the same time had only relative significance due to multiple congenital anomalies of the skull, the formation of which is due to the presence of a rare genetic disease during the life of the deceased, most likely the Hajdu-Cheney or Gorham syndrome. The detection of such a developmental anomaly has a great forensic importance, since the appearance of such people during their lifetime is very specific and contributes to rapid identification of the individual. Thus, it can be argued that a forensic medical research characterized by variability of results, cannot be used in isolation from auxiliary data indicating the presence during life of certain diseases affecting the structure of the skeleton when identifying a person. The expansion of the competence of a forensic medical expert is due to the demands of time, the expansion of the tasks of expertise and methods of their solution. The technologies applied within the framework of the conducted medical and forensic examination made it possible to successfully solve the issues of interest to the investigator and to work out all possible investigative versions of criminal events as objectively as possible.

Disclosures: There is no conflict of interest for all authors.

Acknowledgements: None.

Funding: None. 


\section{References}

1. Arhipkin SV, Koh IA, Gorbunov NS, Klak NN, Chikun VI, Shehovcova JuA. Antropometricheskie metodiki identifikacii lichnosti [in Russian]. Sibirskij medicinskij zhurnal. 2012;112(5):52-55.

2. Roman'ko NA, Zinin AM, Haziev ShN. O sudebno-jekspertnoj identifikacii lichnosti po priznakam vneshnosti i osobennostjam stroenija tela [in Russian]. Sudebnaja medicina. 2017;3(1):21-25.

3. ShvedchikovaTJu, Dubrova SJe, Spiridonov VA. Vozmozhnosti ispol'zovanijakomp'juternoj tomografiipriissledovanii skeletirovannyh ostankov cheloveka [in Russian]. Luchevaja diagnostika i terapija. 2020;3(11):86-96. https://doi.org/10.22328/2079-5343-202011-3-86-96

4. Musabekova SA. Jelementnyj sostav volos kak indikator prirodno-tehnogennoj obstanovki territorii dlja sudebno-medicinskoj identifikacii cheloveka [in Russian]. Medicina i jekologija. 2018;89(4):105-110.

5. Byers SN. Introduction to Forensic Anthropology. 5 edition. New York, London: Routledge; 2016. 502p. https://doi. org/10.4324/9781315642031

6. Konev VP, Shishkina JuO, Moskovskij SN, Korshunov AS, Shestel' IL, Goloshubina VV. Vozmozhnosti ustanovlenija vidovoj prinadlezhnosti kostnyh ostankov metodom atomno-silovoj mikroskopii [in Russian]. Vestn Sudebnoj mediciny. 2018;7(4):25- 30. https://doi.org/10.19048/2411-8729-2018-4-1-22-25

7. Leonov SV, Shakir'janova JuP, Pinchuk PV. Perspektivy razvitija trehmernogo modelirovanija dlja reshenija sudebno-medicinskih jekspertnyh zadach: bim-tehnologija i 4d-modelirovanie [in Russian]. Sudebnaja medicina. 2020;6(1):4-13. https://doi. org/10.19048/2411-8729-2020-6-1-4-13

8. Petrov RV, Jagmurov OD, Bozhchenko AP. Identifikacionnaja znachimost' razmernyh harakteristik tureckogo sedla cherepa vzroslogo cheloveka evropeoidnoj rasy [in Russian]. Vestn Sudebnoj mediciny. 2018;7(4):35- 37.

9. Fedoseev PV, Spirina GA. Morfologicheskaja harakteristika obrazovanij zadnej cherepnoj jamki cheloveka [in Russian]. Mezhdunarodnyj studencheskij vestn. 2015;5(1): 124-127.

10. Dolgov AA, Zolotenkova GV, Titarenko EN. Strukturirovannyj analiz antropologicheskih jekspertiz, vypolnennyh v medikokriminalisticheskom otdele GBUZ MO «Bjuro SMJe» v period s 2007 po 2016 god [in Russian]. Sudebnaja medicina nauka. 2018;4(1):17-21. https://doi.org/10.19048/2411-8729-2018-4-1-17-21

11. Thaer MF, Basim AAl, Abdulrahman NA, Abdulhameed SJ. Craniofacial Anomaly Association with the Internal Malformations in the Pediatric Age Group in Al-Fallujah City-Iraq. BioMed Research International. 2020;2:2314-2333. https://oi. org/10.1155/2020/4725141

12. Lobzin SV, Jurkina EA. Kraniovertebral'nye anomalii: principy sistematizacii, teorii vozniknovenija, klinicheskie projavlenija (obzor literatury) [in Russian]. Vestn Severo-Zapadnogo gosudarstvennogo medicinskogo universiteta im. I. I. Mechnikova. 2014;6(4):8693.

13. Danielle N, Jennifer W, Kavitha R. Psychosocial functioning among children with craniofacial anomalies. Plastic and Reconstructive Surgery. 2015;135(6):1673-1679. https://doi.org/10.1097/PRS.0000000000001269

14. Volpicelli EJ, Pfaff MJ, Hakim K, Bradley JP, Solem RC. Age-related differences in psychosocial function of children with craniofacial anomalies. Plastic and Reconstructive Surgery. 2017;140(4):776-784. https://doi.org/10.1097/PRS.0000000000003687

15. 15. de Heer IM, van Nesselrooij BP, Spliet W, Vermeij-Keers C. Parietal bone agenesis and associated multiple congenital anomalies. J Craniofac Surg. 2003;14(2):192-196. https://doi.org/10.1097/00001665-200303000-00010

16. 16. Sindrom Hajdu - Chejni [Jelektronnyj resurs]: Vikipedija. Svobodnaja jenciklopedija. - URL: https://360wiki.ru/wiki/ Hajdu\%E2\%80\%93Cheney_syndrome (data obrashhenija: 13.09.2021). [in Russian].

17. Erik MS. Sex vs Gender in a Forensic Anthropological Analysis. Nebraska Anthropologist. 2021;29:5-19.

18. Smirnov AV, Sundukov DV. Sudebno-medicinskaja osteologija v Rossii: Aktual'nye problemy i novye tendencii [in Russian]. Sudebnaja medicina. 2019;5(1):166-167. https://doi.org/10.31166/VoprosyIstorii201912Statyi11

19. Gajvoronskij IV, Fandeeva OM, Nichiporuk GI, Gajvoronskaja MG. Sravnitel'naja metodika opredelenija somaticheskogo pola vzroslogo cheloveka po cherepu [in Russian]. Vestn rossijskoj voenno-medicinskoj akademii. 2018;3(63):207-213.

20. Titarenko EN, Fejgin AV. Ispol'zovanie banka dannyh pri jekspertize identifikacii lichnosti [in Russian]. Sudebnaja medicina. 2019;5(1):167-167.

21. Trezubov VN, Popov VL, Rozov RA. Sudebno-stomatologicheskaja identifikacija lichnosti pol'zovatelja polnym s\#emnym protezom [in Russian]. Stomatologija. 2020;99(1):43-48. https://doi.org/10.17116/stomat20209901143

22. Zotova NV, Zolotenkova GV, Poletaeva MP, Vershinina EK. Metodicheskoe obespechenie medikokriminalisticheskih issledovanij po ustanovleniju vozrasta [in Russian]. Sudebnaja medicina. 2019;5(1):167-168. 